\title{
Peran Koneksi Politik dalam Melakukan Tax Avoidance
}

\author{
Moh. Ubaidillah \\ Universitas PGR Madiun \\ mohubaidillah@unipma.ac.id
}

*Penulis Korespondensi

$\begin{array}{ll}\text { Diajukan } & : \text { 1 Januari } 2022 \\ \text { Disetujui } & : \text { 10 Januari } 2022 \\ \text { Dipublikasi } & : 15 \text { Januari } 2022\end{array}$

\section{ABSTRACT}

This research aims to find out the effect of profit management, company size, profitability on tax avoidance with political connections as a moderation variable. The population of this study uses manufacturing companies registered with the IDX in 2017-2020 as many as 193 companies. This sampling technique uses purposive sampling that produces 36 companies. Data analysis techniques use regression analysis with the SPSS 24 tool. The results of this study show that profit management and profitability have a positive effect on tax avoidance. The size of the company has no effect on tax avoidance. Political connections are able to moderate the influence of profit management and profitability to tax avoidance. Political connections do not have the ability to moderate the influence of corporate size on tax avoidance.

Keywords: tax avoidance, earning management; political connection, profitability, company size

\section{PENDAHULUAN}

Pajak merupakan pendapatan negara yang nilainya sangat besar untuk dipakai demi kemakmuran dan kesejahteraan masyarakat. Pajak memberikan kontribusi yang besar bagi pembangunan Negara pada berbagai bidang dari segi pendidikan, kesehatan, industri dan lain sebagainnya (Hidayat, 2018). Untuk itu negara membuat undang-undang perpajakan seperti UU KUP, PPh, PPN dan PPnBM, PBB, Penagihan Pajak, Pengampunan Pajak, dan peraturan lain yang mengatur hal perpajakan lainnya.

Tujuan dibentuknya undang- undang dalam memungut pajak warga negaranya adalah untuk mendapatkan penghasilan negara dari pajak sebesar-besarnya. Munculnya celah-celah dalam undang-undang perpajakan membuat praktik penghindaraan pajak (tax avoidance) sering dilakukan wajib pajak. Penghindaran pajak ini ialah perlawanan aktif yang berasal dari wajib pajak. Hal ini dilakukan ketika SKP (Surat Ketetapan Pajak) belum dikeluarkan. Penghindaran pajak ini dilakukan untuk mengindari kewajiban perpajakan atau untuk mengurangi kewajiban perpajakan. Dalam hal ini praktik tersebut memang tidak melanggar isi dari undang undang tersebut (The letter of law), tetapi tidak mendukung tujuan dibentuknya undang-undang perpajakan tersebut.

Dikutip dari Kompas.com, Republik Indonesia Diperkirakan Rugi Rp 68,7 Triliun Akibat Penghindaran Pajak. Tax Justice Network melaporkan akibat penghindaran pajak, Indonesia diperkirakan merugi hingga 4,86 miliar dollar AS per tahun. Angka tersebut setara dengan Rp 68,7 triliun bila menggunakan kurs rupiah pada penutupan di pasar spot Senin (22/11/2020) sebesar Rp 14.149 per dollar Amerika Serikat (AS). Dalam laporan Tax Justice Network yang berjudul The State of Tax Justice 2020: Tax Justice in the time of Covid-19 disebutkan, dari angka tersebut, sebanyak 4,78 miliar dollar AS setara Rp 67,6 triliun diantaranya merupakan buah dari pengindaran pajak korporasi di Indonesia. Sementara sisanya 78,83 juta dollar AS atau sekitar Rp 1,1 triliun berasal dari wajib pajak orang orang pribadi.

Salah satu faktor penentu tax avoidance adalah manajemen laba. Manajemen laba didefinisikan sebagai upaya manajer perusahaan untuk mengintervensi atau memengaruhi informasi dalam laporan keuangan dengan tujuanuntuk mengelabui stakeholder yang ingin mengetahui kinerja dan kondisi perusahaan. 
Manajemen laba adalah salah satu faktor yang dapat mengakibatkan konflik agen dan principal. Sebagai agen, manajer secara moral bertanggung jawab untuk mengoptimalkan keuntungan para pemilik (principal) dan sebagai imbalannya akan memperoleh kompensasi sesuai dengan kontrak. Dengan demikian terdapat dua kepentingan yang berbeda didalam perusahaan dimana masing-masing pihak berusaha untuk mencapai atau mempertahankan tingkat kemakmuran yang dikehendaki. Manajemen Laba (Earnings Management) terjadi ketika para manajer menggunakan pertimbangan mereka dalam pelaporan keuangan dan struktur transaksi untuk mengubah laporan keuangan dengan tujuan untuk menyesatkan pemangku kepentingan mengenai kondisi kinerja ekonomi perusahaan atau untuk memengaruhi hasil-hasil kontraktual yang bergantung pada angka-angka akuntansi yang dilaporkan untuk memperoleh insentif dari hasil kinerjanya yang diukur dari besarnya laba yang dicapai.

Faktor penentu tax avoidance lainnya yaitu ukuran perusahaan. Ukuran perusahaan diketahui dari besarnya total aset yang dimiliki oleh sebuah perusahaan. Semakin besar ukuran sebuah perusahaan, maka perusahaan tersebut akan lebih mempertimbangkan risiko-risiko dalam mengelola beban pajaknya (Handayani, 2018). Penelitian terdahulu yaitu oleh Suryani (2020) dan Oktamawati (2017) menyebutkan ukuran perusahaan berpengaruh negatif terhadap penghindaran pajak. Penelitian lain oleh Okrayanti et al. (2017) dan Handayani (2018) menyebutkan ukuran perusahaan berpengaruh positif terhadap penghindaran pajak. Sedangkan penelitian dari Faizah \& Adhivinna (2017), Khairunisa et al. (2017), dan Cahyono et al. (2016) menunjukkan bahwa ukuran perusahaan tidak berpengaruh terhadap penghindaran pajak.

Subagiastra et al. (2016) meneliti pengaruh antara profitabilitas dengan penghindaran pajak dan ditemukan hasil yang positif. Namun hasil berbeda ditunjukkan oleh Siregar \& Widyawati (2016), Krisdiantoro et al. (2019), (Mardianti \& Ardini (2020) yang menyebutkan bahwa profitabilitas tidak memiliki pengaruh terhadap penghindaran pajak. Menurut Dewi et al. (2019) Profitabilitas yaitu sebuah gambaran kinerja keuangan perusahaan dalam laba yang berasal dari pengelolaan aset atau dikenal dengan istilah Return On Asset (ROA). Tingkat Profitabilitas yang tinggi akan mendorong manajemen untuk menghasilkan pajak optimal dengan meminimalkan beban pajak, sehingga perusahaan cenderung melakukan tax avoidance (Nugrahitha \& Suprasto, 2018).

Perusahaan dengan koneksi politik yaitu perusahaan yang memiliki hubungan dekat dengan pemerintah yang menyebabkan perusahaan akan mendapatkan berbagai hak-hak istimewa layaknya kemudahan untuk mendapatkan pinjaman, resiko pemeriksaan pajak yang rendah, dan lain sebagainya yang menyebabkan perusahaan cenderung akan melakukan penghindaran pajak (Annisa, 2017). Penelitian oleh Asadanie \& Venusita (2020) menyimpulkan bahwa koneksi politik berpengaruh negatif terhadap penghindaran pajak. Sedangkan penelitian dari (Munawaro \& Ramdany, 2020) menyatakan bahwa koneksi politik berpengaruh terhadap penghindaran pajak.

Berdasarkan hasil penelitian terdahulu diperoleh adanya perbedaan hasil penelitian yang dilakukan oleh para peneliti dan berdasarkan latar belakang yang telah diuraikan di atas, maka tujuan penelitian akan melakukan penelitian yang berjudul "Pengaruh Manajemen Laba, Ukuran Perusahaan, Profitabilitas Terhadap Tax Avoidance Dimoderasi Oleh Koneksi Politik". Keterbaruan dari penelitian ini dengan penelitian sebelumnya adalah penggunaan variabel independen yang belum menunjukkan hasil konsisten untuk diuji ulang dan penggunaan rentang waktu terbaru yaitu 2018-2020 dengan menambahkan variabel moderasi koneksi politik untuk menguji apakah variabel tersebut memoderasi pengaruh variabel independen terhadap variabel dependen.

\section{Teori Keagenan}

\section{STUDI LITERATUR}

Jensen dan Meckling (1976) menerangkan agency theory ialah teori yang berhubungan dengan keagenan selaku kontrak antara pemberi kerja (principal) dengan yang dipekerjakan (agent) dengan tujuan membantu perusahaan dalam mengambil keputusan yang akan diambil perusahaan. Pemberi kerja memiliki kewenangan untuk memberikan kekuasaan kepada manajer perusahaan untuk mengatur dan membuat berbagai keputusan. 
Menurut (Rahmadani et al., 2020), akan timbul suatu masalah apabila dalam hubungan antara agent dan principal terdapat informasi yang asimetri (asymmetry information). Hal ini terjadi ketika manajemen sebagai pihak yang mempunyai akses langsung pada informasi perusahaan tidak mengungkapkan beberapa informasi kepada pihak eksternal perusahaan termasuk kepada investor sebagai prinsipal.

Principal (pemegang saham) mengharapkan manajer dapat bekerja dengan tujuan memaksmimumkan kemakmuran pemegang saham, namun berbeda dengan manajer perusahaan bisa saja bertindak sebaliknya yaitu dengan memaksimumkan kemakmuran mereka sendiri di atas kemakmuran pemegang saham. Kondisi seperti ini cenderung memicu tindakan yang tidak sesuai. Contohnya yaitu manipulasi laporan keuangan dengan manajemen laba perusahaan.

Adanya perbedaan pemikiran antara manajer dengan pemegang sahamdalam mengatur perusahaan menimbulkan manajemen bertindak tidaksesuai dengan keinginan prinsipal, sehingga dapat memicu konflikkeagenan atau agency conflict (Hutapea \& Herawaty, 2020). Konflik keagenan dalam penelitian ini ialah berkaitan dengan hal pemungutan pajak dan pembayaran pajak. Pemerintah mengharapkan pemungutan pajak yang dilakukan dapat menjadi pemasukan yang besar untuk negara, di lain pihak yaitu wajib pajak atau badan beranggapan sebaliknya, yaitu perusahaan harus menghasilkan keuntungan yang besar dengan beban pajak tertanggung yang rendah.

\section{Hipotesisi Penelitian \\ Pengaruh Manajemen Laba Terhadap Tax Avoidance}

Berdasarkan teori keagenan (Agency Theory) manajemen laba adalah salah satu faktor yang dapat mengakibatkan konflik agen dan principal. Sebagai agen, manajer secara moral bertanggung jawab untuk mengoptimalkan keuntungan para pemilik (principal) dan sebagai imbalannya akan memperoleh kompensasi sesuai dengan kontrak. Dengan demikian terdapat dua kepentingan yang berbeda didalam perusahaan dimana masing-masing pihak berusaha untuk mencapai atau mempertahankan tingkat kemakmuran yang dikehendaki.

Manajemen Laba (Earnings Management) terjadi ketika para manajer menggunakan pertimbangan mereka dalam pelaporan keuangan dan struktur transaksi untuk mengubah laporan keuangan dengan tujuan untuk menyesatkan pemangku kepentingan mengenai kondisi kinerja ekonomi perusahaan atau untuk memengaruhi hasil-hasil kontraktual yang bergantung pada angkaangka akuntansi yang dilaporkan. Menurut Silvia (2017) mengungkapkan bahwa manajemen laba berpengaruh terhadap tax avoidance. Hal ini menunjukkan bahwa semakin tinggi tingkat laba suatu perusahaan maka akan semakin tinggi penghindaran pajak yang dilakukan oleh perusahaan. Dengan demikian hipotesis pada penelitian ini adalah sebagai berikut:

H1: Manajemen Laba Berpengaruh Positif terhadap tax avoidance.

\section{Pengaruh Ukuran Perusahaan Terhadap Tax Avoidance.}

Ukuran perusahaan (firm size) menggambarkan bagaimana kemampuan aktivitas ekonomi perusahaan dan kestabilannya serta tindakan pengembalian keputusan perpajakan. Besar atau kecilnya ukuran perusahaan dapat diukur dari nilai ekuitas, penjualan, total karyawan, dan total aset. Perusahaan yang memiliki total aset besar akan lebih mampu dan stabil dalam menghasilkan keuntungan jika dibandingkan dengan perusahaan yang total asetnya lebih kecil. Sehingga keadaan laba besar tersebut memicu perusahaan untuk melakukan penghindaran pajak (tax avoidance). Semakin besar perusahaan maka semakin kompleks transaksinya sehingga menimbulkan celah untuk melakukan tindakan penghindaran pajak (tax avoidance) (Rego, 2003). Hal ini sejalan dengan penelitian Swingly \& Sukartha (2015) dan Siregar \& Widyawati (2016) menjelaskan bahwa ukuran perusahaan berpengaruh positif terhadap penghindaran pajak. Berdasarkan uraian tersebut, penelitian ini mengajukan hipotesis sebagai berikut :

H2: Ukuran Perusahaan Berpengaruh Positif Terhadap Tax Avoidance

\section{Pengaruh Profitabilitas Terhadap Tax Avoidance}

Return on asset (ROA) merupakan salah satu pendekatan yang dapat mencerminkan profitabilitas suatu perusahaan. Pendekatan ROA menunjukkan bahwa besarnya laba yang diperoleh perusahaan dengan menggunakan total aset yang dimilikinya (Darmawan \& Sukartha, 
2014). ROA juga memperhitungkan kemampuan perusahaan dalam menghasilkan laba yang terlepas dari pendanaan. Semakin tinggi ROA (return on asset) perusahaan maka semakin besar laba yang diperoleh perusahaan dan sebaliknya, semakin rendah ROA maka semakin sedikit laba yang diperoleh perusahaan. Semakin tinggi laba yang diperoleh perusahaan maka jumlah pajak pengahasilan juga akan semakin meningkat sesuai dengan peningkatan laba perusahaan. Hal tersebut akan mendorong perusahaan untuk melakukan tindakan penghindaran pajak (tax avoidance) (Dewinta \& Setiawan, 2016).

Penelitian yang dilakukan oleh Darmawan \& Sukartha (2014), Budianti \& Curry (2018) dan Dewinta \& Setiawan (2016) membuktikan bahwa ROA (Return On Asset) berpengaruh positif signifikan terhadap penghindaran pajak (tax avoidance). Berdasarkan penjelasan tersebut maka hipotesis yang dibangun adalah sebagai berikut:

H3 : Profitabilitas Berpengaruh Terhadap Tax Avoidance

\section{Pengaruh Manajemen Laba Terhadap Tax Avoidance dengan Koneksi Politik sebagai Variabel Moderasi}

Manajemen laba adalah salah satu faktor yang dapat mengakibatkan konflik agendan principal. Sebagai agen, manajer secara moral bertanggung jawab untuk mengoptimalkan keuntungan para pemilik (principal) dan sebagai imbalannya akan memperoleh kompensasi sesuai dengan kontrak. Dengan demikian terdapat dua kepentingan yang berbeda didalam perusahaan dimana masing-masing pihak berusaha untuk mencapai atau mempertahankan tingkat kemakmuran yang dikehendaki. Manajemen Laba (Earnings Management) terjadi ketika para manajer menggunakan pertimbangan mereka dalam pelaporan keuangan dan struktur transaksi untuk mengubah laporan keuangan dengan tujuan untuk menyesatkan pemangku kepentingan mengenai kondisi kinerja ekonomi perusahaan atau untuk memengaruhi hasil-hasil kontraktual yang bergantung pada angka-angka akuntansi yang dilaporkan.

Di lain sisi, Perusahaan yang memiliki koneksi politik memiliki tingkat manajemen pajak yang tinggi. Koneksi politik merupakan suatu kondisi di mana terjalin suatu hubungan antara pihak tertentu dengan pihak yang memiliki kepentingan dalam politik yang digunakan untuk mencapai suatu hal tertentu yang dapat menguntungkan kedua belah pihak (Sugiyarti, 2017). Perusahaan yang memiliki koneksi politik dengan pemerintah yang sedang berkuasa terbukti memiliki tingkat tax avoidance yang signifikan tinggi jika dibandingkan denganperusahaan sejenis yang tidak memiliki koneksi politik (Kim dan Zhang, 2013).

H4: Manajemen Laba Berpengaruh Positif terhadap Tax Avoidance dengan Koneksi Politik sebagai Variabel Moderasi

\section{Pengaruh Ukuran Perusahaan Terhadap Tax Avoidance dengan Koneksi Politik sebagai Variabel Moderasi}

Ukuran perusahaan dapat menggambarkan keadaan sumber daya pada suatu perusahaan, dengan begitu cara perusahaan dalam menjalankan kewajiban perpajakannya dapat dipengaruhi oleh ukuran perusahaannya dan ukuran suatu perusahaan merupakan salah satu faktor dilakukannya praktik penghindaran pajak. Tidak jarang ukuran perusahaan yang besar beroperasi antar negara, kondisi seperti inilah yang akan menimbulkan kecenderungan pihak perusahaan untuk melakukan praktik penghindaran pajak (tax avoidance) lebih tinggi jika dibandingkan dengan perusahaan yang beroperasi hanya didalam negara saja. Penelitian beberapa tahun terakhir ini juga telah banyak membahas mengenai ukuran perusahaan, diantaranya penelitian Dewinta \& Setiawan (2016) yang mengungkapkan bahwa ukuran perusahaan berpengaruh signifikan secara parsial terhadap tax avoidance.

Perusahaan dikatakan memiliki hubungan politik yaitu jika perusahaan memiliki ikatan secara politik atau mengupayakan adanya kedekatan dengan pemerintah dengan cara-cara yang dilakukan oleh pihak perusahaan. Hubungan politik sendiri diyakini untuk kebanyakan perusahaan merupakan aset yang sangat berharga (Leuz \& Oberholzer-gee, 2006). Berdasarkan uraian tersebut, penelitian ini mengajukan hipotesis sebagai berikut.

H5: Ukuran Perusahaan Berpengaruh Positif terhadap Tax Avoidance dengan Koneksi Politik Memoderasi 


\section{Pengaruh Profitabilitas Terhadap Tax Avoidance dengan Koneksi Politik sebagai variabel Moderasi}

Proksi profitabilitas salah satunya menggunakan Return On Assets (ROA), yaitu dengan membandingkan laba perusahaan dengan total aset yang dimiliki. Besarnya nilai return on assets dapat mempengaruhi nilai cash effective tax rate. Proksi profitabilitas salah satunya menggunakan Return On Assets (ROA), yaitu dengan membandingkan laba perusahaan dengan total aset yang dimiliki. Besarnya nilai return on assets dapat mempengaruhi nilai cash effective tax rate. Mengukur praktik tax avoidance salah satunya dengan menghitung cash effective tax rate. Jika return on assets semakin tinggi, maka nilai CETR semakin rendah, karena aktivitas yang dilakukan terhadap tax avoidance semakin besar. Perusahaan yang nilai profitabilitasnya besar berpeluang untuk melakukan perencanaan pajak yang matang dengan didukung oleh jasa konsultan sehingga dapat meminimalkan pembayaran pajak perusahaan.

Peluang yang dimiliki oleh perusahaan yang mempunyai profitabilitas tinggi yaitu berkesempatan untuk memposisikan perencanaan pajak perusahaan sehingga beban kewajiban perpajakan yang harus ditanggung perusahaan berkurang (Chen et al. 2010). Peran manajemen keuangan yang baik tidak terlepas dalam menghasilkam profitabilitas tinggi yang dimiliki suatu perusahaan. Salah satu cara manajemen keuangan untuk mempertahankan profitabilitas yang tinggi dan stabil perlu adanya tax planning. Disisi lain koneksi politik sangatlah berpengaruh. Perusahaan berkoneksi politik merupakan perusahaan yang memiliki hubungan dengan pemerintah atau mengupayakan kedekatan antara pihak perusahaan dengan pemerintah. Koneksi politik diyakini bagi kebanyakan perusahaan sebagai suatu aset yang berharga (Leuz and Gee, 2006). Pendapat tersebut didukung dengan penelitian Dewinta \& Setiawan (2016), dimana penelitian tersebut mengungkapkan bahwa profitabilitas berpengaruh terhadap penghindaran pajak. Berdasarkan uraian tersebut, penelitian ini mengajukan hipotesis sebagai berikut:

H6: Profitabilitas Berpengaruh Positif Terhadap Tax Avoidance dengan Koneksi Politik sebagai Variabel Mderasi

\section{METODE}

Penelitian ini dilakukan di perusahaan manufaktur yang terdaftar di Bursa Efek Indonesia (BEI) periode 2017-2020. Tektik pengumpulan data menggunakan teknik purposive sampling dengan kriteria sebagai berikut.

- Perushaaan manufaktur yang terdaftar di Bursa Efek Indonesia secara konsisten di tahun 2017-2020

- Perusahaan yag tidak terdaftar secara berturut turut periode tahun 2017-2020

- Perusahaan yang tidak menerbitkan laporan keuangan per 31 Desember secara konsisten 2017-2020

- Perusahaan yang tidak menerbitkan laporan keuangan dalam mata uang Rupiah secara konsistensi dari tahun 2017-2020

Perusahaan yang tidak menghasilkan laba secara konsisten dari tahun 2017-2020

\section{Pengukuran Variabel}

\section{Tax Avoidance}

Tax Avoidance (Penghindaran pajak) dalam penelitian ini diukur menggunakan rasio ef ective tax rates (ETR) (Suripto dan Sugiyanto, 2021). Ef ective Tax Rates (ETR) dalam penelitian ini hanya menggunakan model utama yang digunakan penghasilan dibagi dengan pendapatan sebelum pajak perusahaan. Rasio Ef ective Tax Rates (ETR) diukur dengan perhitungan sebagai berikut :

\section{Manajemen Laba}

$$
\text { Effective Tax Rates (ETR) } \quad=\frac{\text { Pembayaran Pajak/Beban Pajak }}{\text { Laba Sebelum Pajak }}
$$

Manajemen laba (Y) merupakan korelasi laba akuntansi suatu perusahaan terhadap laba ekonominya. Menurut standar akuntansi, manajemen laba pada suatu perusahaan diperbolehkan selama dalam praktiknya perusahaan mampu untuk mengungkapkan secara jelas informasi yang bersangkutan sehingga tidak menimbulkan kerugian terhadap pihak-pihak yang berkepentingan (Mawardi, 2019). Perhitungan manajemen laba menggunakan model discretionary accrual yang 
telah dimodifikasi oleh (Dechow, et al., 1995) yaitu Jones Model. Model penghitungannya sebagai berikut :

TACit=NIit-CFOit

Total accrual diestimasi persamaan regresi OLS (Ordinary Least Square) : TACit/TAit$1=\alpha i(1 /$ TAit-1) $+\beta 1 i[(" R E V i t /$ TAit-1) $]+\beta 2 i($ PPEit/TAit-1) $+\varepsilon$ Non Accruals Discretioner :

NDTACit $=\alpha i(1 /$ TAit-1) $+\beta 1 i("$ REVit-RECit/TAt-1)/TAit-1 $+\beta 2 i($ PPEit $/$ TAit-1) $=\varepsilon$

Discretioner Total Accrual merupakan residual yang diperoleh dari total accrual : DTACit=(TACit/TAit-1)-NDTACit

Keterangan :

\begin{tabular}{|l|l|}
\hline DTACit & $=$ Discretionary accrual perusahaan $\mathrm{i}$ pada periode $\mathrm{t}$ \\
\hline NDTAC & $=$ Non Discretionary accrual perusahaan $\mathrm{i}$ pada periode $\mathrm{t}$ \\
\hline NIit & $=$ Net Income perusahaan $\mathrm{i}$ pada periode $\mathrm{t}$ \\
\hline TACit & $=$ Total accrual perusahaan $\mathrm{i}$ pada periode $\mathrm{t}$ \\
\hline CFOit & $=$ Aliran arus kas operasi perusahaan $\mathrm{i}$ pada periode $\mathrm{t}$ \\
\hline TAit-1 & $=$ Total aktiva perusahaan i pada periode $\mathrm{t}$ \\
\hline$\Delta$ REVit & $=$ Perubahan penjualan perusahaan i pada periode $\mathrm{t}$ \\
\hline $\begin{array}{l}\text { PPEit } \\
\text { RECit }\end{array}$ & $\begin{array}{l}=\text { Aktiva tetap perusahaan i pada periode } \mathrm{t} \\
=\text { Perubahan piutang perusahaan } \mathrm{i} \text { pada periode } \mathrm{t}\end{array}$ \\
\hline
\end{tabular}

\section{Ukuran Perusahaan}

Cahyono, et al (2016) mengartikan ukuran perusahaan sebagai skala atau nilai yang dapat mengklasifikasikan suatu perusahaan kedalam kategori besar atau kecil menurut berbagai cara seperti total aktiva atau total aset perusahaan, nilai pasar saham, rata-rata tingkat penjualan dan jumlah penjualan. Ukuran perusahaan dapat menujukan kestabilan serta kemampuan perusahaan dalam melakukan aktivitas ekonominya Munandar, Nazar, dan Khairunnisa (2016). Ukuran perusahaan diketahui dari besarnya total aset yang dimiliki oleh sebuah perusahaan. Semakin besar ukuran sebuah perusahaan, maka perusahaan tersebut akan lebih mempertimbangkan risiko-risiko dalam mengelola beban pajaknya (Handayani, 2018). Apabila ukuran perusahaan itu besar maka perusahaan tersebut akan dapat menarik perhatian dari pemerintah dan para manajer akan cenderung berlaku patuh atau agresif dalam menentukan kebijakan yang berkaitan dengan pajak. Ukuran untuk menentukan firm size adalah dengan log natural dari total aktiva.

Ukuran Perusahaan $=$ Ln. Total Assets

\section{Profitabilitas}

Rasio profitabilitas merupakan serangkaian dari keputusan manajemen. Rasio ini digunakan untuk mengukur sebuah kemampuan perusahaan guna memperoleh laba yang didapat dari penjualan dan pendapatan investasi (Kasmir, 2014). Semakin baik profitabilitas, maka akan semakin tinggi kemampuan perusahaan untuk memperoleh keuntungan. sebaliknya jika semakin rendah rasio profitabilitas, maka akan semakin rendah tingkat kemampuan perusahaan untuk mendapatkan keuntungan.

$$
\text { Return on Assets } \quad=\frac{\text { Laba bersih }}{\text { Total Asset }}
$$

\section{Koneksi Politik}

Menurut Gomez \& Jomo (2009) dalam Pranoto \& Widagdo (2015), perusahaan yang mempunyai koneksi politik merupakan perusahaan atau konglomerat yang mempunyai hubungan dekat dengan pemerintah. Perusahaan yang mempunyai hubungan dekat dengan pemerintah dapat diartikan sebagai perusahaan milik pemerintah, yaitu perusahaan yang berbentuk BUMN atau BUMD. Konglomerat (pemilik) yang mempunyai hubungan dekat dengan pemerintah adalah konglomerat atau pemilik perusahaan yang merupakan tokoh politik terkemuka. Tokoh politik tersebut merupakan anggota atau mantan anggota dewan di pemerintahan pusat atau militer.

\section{Teknik Analisis Data}


Teknik analisis data penelitian ini menggunakan uji statistik deskriptif, uji asumsi klasik yang meliputi (uji normalitas, uji multikolinieritas, uji heteroskedastisitas, dan uji autokorelasi) analisis regresi berganda dengan uji $\mathrm{T}$ dan moderated regression analysis (MRA) dengan bantuan software SPSS versi 21.

\section{HASIL}

Populasi dalam penelitian ini adalah seluruh perusahaan manufaktur yangterdaftar di Bursa Efek Indonesia (BEI) periode 2017-2020 sebanyak 193 perusahaan manufaktur. Sampel perusahaan yang berhasil diperoleh dalam penelitian ini sebanyak 36 perusahaan dengan total data sebanyak 180 selama 5 tahun. Sampel yang digunakan pada penelitian ini dipilih dengan menggunakan metode purposive sampling sebagai syarat yang harus dipenuhi untuk menjadi sampel penelitian.

\section{Hasil Olah data}

\section{Uji Asumsi Klasik}

a. Uji Normalitas

Tabel 1 Uji Normalitas

One-Sample Kolmogorov-Smirnov Test

\begin{tabular}{|l|l|l|}
\hline \multicolumn{2}{|l|}{} & $\begin{array}{l}\text { Unstandardized } \\
\text { Residual }\end{array}$ \\
\hline N & 84 \\
\hline Normal Parameters ${ }^{\text {a,b }}$ & Mean &, 0000000 \\
\cline { 2 - 3 } & Std. Deviation & 3,34427669 \\
\hline \multirow{2}{*}{ Most Extreme Differences } & Absolute & 091 \\
\cline { 2 - 3 } & Positive &, 091 \\
\cline { 2 - 3 } & Negative &,- 069 \\
\hline Test Statistic &, 091 \\
\hline Asymp. Sig. (2-tailed) &, $070^{c}$ \\
\hline
\end{tabular}

Sumber: data diolah (2021)

Pada hasil pengujian di atas diketahui bahwa nilaTi Asymp. Sig (2-tailed) adalah 0,070. Hasil tersebut lebih besar dari 0,05 , maka jenis penelitian ini dapat disimpulkan berdistribusi normal.

b. Uji Multikoleniaritas

\section{Coefficients ${ }^{\mathrm{a}}$}

Tabel 2 Uji Multikoleniaritas

\begin{tabular}{|l|l|r|r|}
\hline \multirow{2}{*}{ Model } & \multicolumn{2}{|l|}{ Collinearity Statistics } \\
\cline { 3 - 4 } \multicolumn{2}{|l|}{21} & Tolerance & VIF \\
\cline { 2 - 4 } & Constant) & & \\
\cline { 2 - 4 } & Manajemen Laba &, 907 & 1,105 \\
\cline { 2 - 4 } & Ukuran Perusahaan &, 906 & 1,101 \\
\cline { 2 - 4 } & Profitabilitas &, 837 & 1,219 \\
\hline
\end{tabular}

Sumber: data diolah (2021)

Hasil tabel diatas menunjukkan nilai yang dapat diketahui ada atau tidaknya multikoliniearitas ialah dalam nilai toleerance yaitu $>0,10$ atau nilai $\mathrm{VIF}<10$, pada pengujian diatas dihasilkan tidak adanya korelasi pada variabel independen.

c. Uji Heterokedasitas

Tabel 3 Uji Heteroskedastisitas

Corelation

\begin{tabular}{|l|l|l|l|l|}
\hline & IM & UK & P & $\begin{array}{l}\text { Unstandardized } \\
\text { Residual }\end{array}$ \\
\hline
\end{tabular}


Owner: Riset \& Jurnal Akuntansi

e-ISSN : 2548-9224|p-ISSN : 2548-7507

Volume 6 Nomor 1, Januari 2022

DOI : https://doi.org/10.33395/owner.v6i1.667

\begin{tabular}{|c|c|c|c|c|c|c|}
\hline \multirow[t]{9}{*}{ Spearman's rho } & \multirow[t]{3}{*}{ Manajemen Laba } & $\begin{array}{l}\text { Correlation } \\
\text { Coefficient }\end{array}$ & 1.000 & -.008 & $-.288^{* *}$ & -.023 \\
\hline & & Sig. (2-tailed) & & .940 & .008 & .843 \\
\hline & & $\mathrm{N}$ & 84 & 84 & 84 & 84 \\
\hline & \multirow[t]{3}{*}{$\begin{array}{l}\text { Ukuran } \\
\text { Perusahaan }\end{array}$} & $\begin{array}{l}\text { Correlation } \\
\text { Coefficient }\end{array}$ & -.008 & 1.000 & $.294^{* *}$ & .100 \\
\hline & & Sig. (2-tailed) & .940 & & .007 & .355 \\
\hline & & $\mathrm{N}$ & 84 & 84 & 84 & 84 \\
\hline & \multirow[t]{3}{*}{ Profitabilitas } & $\begin{array}{l}\text { Correlation } \\
\text { Coefficient }\end{array}$ & $-.288^{* *}$ & $.294^{* *}$ & 1.000 & .037 \\
\hline & & Sig. (2-tailed) & .008 & .007 & & .747 \\
\hline & & $\mathrm{N}$ & 84 & 84 & 84 & 84 \\
\hline
\end{tabular}

Sumber: data diolah (2021)

Diketahui tabel diatas menunjukkan bahwa hasil pengujian pengaruh masing-masing varaibel independen memiliki nilai signifikansi dari variable manajemen laba sebesar 0,843 , yang lebih besar dari 0,05 . Nilai signifikansi dari variabel ukuran perusahaan sebesar 0,355 , yang lebih besar dari 0,05. Sedangkan nilai signifikansi dari variabel profitabilitas sebesar 0,747 , yang lebih besar dari 0,05. Diketahui seluruh nilai signifikansi atau sig. (2-tailed) dari variabel independen lebih besar dari 0,05 maka dinyatakan pengujian tersebut tidak terjadinya heteroskedastisitas.

Tabel 4 Uji Autokorelasi

Model Summary ${ }^{\mathrm{b}}$

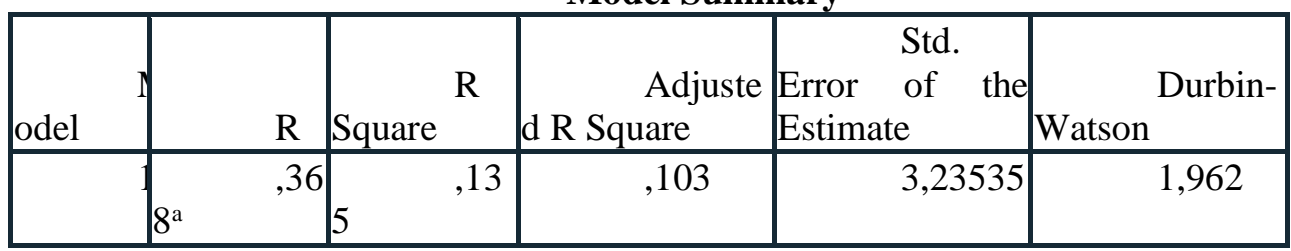

Sumber: data diolah (2021)

Berdasarkan tabel diatas, dapat diketahui bahwa nilai DW adalah sebesar 1,963. Nilai DU pada tabel Durbin Watson di dapat 1,719. Nilai $4-\mathrm{Du}=2,281$. Sehingga terjadi kategori DU < DW $<(4-D u)$ atau $1,719<1,963<2,281$. Dengan demikian model yang diajukan dalam penelitian tidak terjadi Autokorelasi

\section{Uji Hipotesis}

Tabel 5 Uji Hipotesis

\begin{tabular}{|c|c|c|}
\hline \multicolumn{3}{|l|}{ Coefficients ${ }^{\mathrm{a}}$} \\
\hline & $\mathrm{t}$ & Sig. \\
\hline \multicolumn{3}{|l|}{ Model } \\
\hline 1 (Constant) & 1,968 &, 053 \\
\hline Manajemen Laba & 2,144 & ,047 \\
\hline Ukuran Perusahaan &, 597 &, 553 \\
\hline Profitabilitas & 2,203 &, 031 \\
\hline Moderasi_X1 & 2,146 & ,035 \\
\hline Moderasi_X2 &,- 419 & ,683 \\
\hline Moderasi_X3 & 2,855 &, 007 \\
\hline
\end{tabular}

Sumber: data diolah (2021) 
Hasil olah data tabel diatas bahwa variabel manajemen laba berpengaruh terhadap tax avoidance. Berdasarkan analisis data menunjukkan bahwa nilai Sig. sebesar 0,047 > probabilitas 0,05 . Nilai thitung sebesar 2,144 < ttabel 1,989. Dengan demikian H1 diterima.

Variabel Ukuran Perusahaan tidak berpengaruh terhadap variabel tax avoidance. Berdarsarkan analisis data menunjukkan bahwa Nilai Sig. sebesar 0,553 > Probabilitas 0,05. Nilai t hitung sebesar 0,597 < t tabel 1,989. Dengan demikian H2 ditolak.

variabel Profitabilitas berpengaruh terhadap variabel tax avoidance. Berdasarkan analisis data menunjukkan bahwa nilai Sig. sebesar 0,031 < probabilitas 0,05 . Nilai t hitung sebesar $-2,203$ $>\mathrm{t}$ tabel 1,989. Dengan demikian H3 diterima.

variabel Koneksi Politik mampu memoderasi variabel manajemen laba terhadap tax avoidance. Berdasarkan analisis data menunjukkan bahwa Nilai Sig. sebesar 0,035 < probabilitas 0,05 . Nilai t hitung sebesar 2,146 < t tabel 1,989. Dengan demikian H4 diterima.

variabel Koneksi Politik tidak mampu memoderasi variabel Ukuran Perusahaan. Berdasarkan analisis data menunjukkan bahwa Nilai Sig. sebesar 0,683 < probabilitas 0,05. Nilai $t$ hitung sebesar 0,419 > t tabel 1,989. Dengan demikian H5 ditolak.

variabel Koneksi Politik mampu memoderasi variabel Profitabilitas. Berdasarkan analisis data menunjukkan bahwa Nilai Sig. sebesar $0,007<$ probabilitas 0,05. Nilai t hitung sebesar 2,855 $<\mathrm{t}$ tabel 1,989. Dengan demikian H6 diterima

\section{PEMBAHASAN}

Hasil uji hipotesis pertama menunjukkan bahwa manajemen laba berpengaruh positif terhadap tax avoidance. Hal ini sesuai dengan hipotesis peneliti. Tindakan manajemen laba akan mempengaruhi besarnya beban pajak yang dibayarkan. Manajer bertindak oportunistik akibat dari asimetris informasi yaitu dengan melakukan manajemen laba dengan motivasi pajak (taxation motivation) sehingga tindakan manajemen laba mempengaruhi besarnya pajak yang dibayarkan.

Hasil uji hipotesis kedua pada penelitian ini mengindikasikan bahwa besar atau kecilnya ukuran perusahaan tidak mempengaruhi aktivitas penghindaran pajak. Perusahaan dengan aset yang tinggi cenderung dapat menghasilkan laba yang stabil dibandingkan dengan perusahaan dengan aset lebih kecil, sehingga perusahaan dengan aset yang tinggi lebih mampu dalam mengelola dan membayar kewajiban pajaknya.

Hasil olah data menunjukkan bahwa profitabilitas berpengaruh positif terhadap tax avoidance. Hal ini sesuai dengan hipotesis peneliti. Semakin tinggi tingkat profitabilitas perusahaan maka semakin tinggi pula tingkat penghindaran pajak suatu perusahaan yang disebabkan karena perusahaan dengan laba yang besar akan lebih leluasa untuk memanfaatkan celah terhadap pengelolaan beban pajaknya.

Hasil olah data menunjukkan bahwa koneksi politik mampu memoderasi pengaruh manajemen laba terhadap tax avoidance. Manajemen Laba terjadi ketika para manajer menggunakan pertimbangan mereka dalam pelaporan keuangan dan struktur transaksi untuk mengubah laporan keuangan dengan tujuan untuk menyesatkan pemangku kepentingan mengenai kondisi kinerja ekonomi perusahaan atau untuk memengaruhi hasil-hasil kontraktual yang bergantung pada angka-angka akuntansi yang dilaporkan. Di lain sisi, Perusahaan yang memiliki koneksi politik memiliki tingkat manajemen pajak yang tinggi. Koneksi politik merupakan suatu kondisi di mana terjalin suatu hubungan antara pihak tertentu dengan pihak yang memiliki kepentingan dalam politik yang digunakan untuk mencapai suatu hal tertentu yang dapat menguntungkan kedua belah pihak. Sehingga adanya koneksi politik, manajemen laba akan memudahkan melakukan tax avoidance.

Hasil olah data menunjukkan bahwa koneksi politik tidak mampu memoderasi pengaruh ukuran perusahaan terhadap tax avoidance. Hasil ini tidak sesuai dengan hipotesis peneliti. Perusahaan besar yang memiliki koneksi politik akan lebih menghindari kegiatan berisiko seperti kegiatan manajemen pajak agresif, resiko tersebut baik denda ataupun buruknya reputasi perusahaan dimata publik apabila melakukannya. Dalam peraturan perpajakan juga tidak terdapat aturan tentang tinggi atau rendahnya tarif pajak dalam hubungan politik, semakin tinggi tingkat koneksi politik maka tidak mempengaruhi tindakan penghindaran pajak perusahaan. 
Hasil olah data menunjukkan bahwa koneksi politik mampu moderasi pengaruh profitabilitas terhadap tax avoidance. Hal ini sesuai dengan hipotesis peneliti. Koneksi politik suatu perusahaan apabila dibina dengan baik untuk memperkuat posisi perusahaan terhadap pemerintah dapat digunakan perusahaan untuk lebih terlibat dalam kegiatan manajemen pajak. Posisi yang kuat akan mempermudah perusahaan dalam memperoleh dukungan pemerintah berupa fasilitas pemeriksaan yang lebih rendah daripada perusahaan yang tidak memiliki koneksi politik dengan pemerintahan. Umumnya perusahaan manufaktur yang dimiliki oleh orang-orang yang berkepentingan di pemerintahan memiliki pengaruh kuat untuk melakukan manajemen pajak.

\section{KESIMPULAN}

Hasil penelitian ini dapat disimpulkan bahwa manajemen laba berpengaruh positif terhadap tax avoidance. Ukuran perusahaan tidak berpengaruh terhadap tax avoidance. Profitabilitas berpengaruh positif terhadap tax avoidance. Koneksi politik mampu memoderasi pengaruh manajemen laba terhadap tax avoidance. koneksi politik tidak mampu memoderasi pengaruh ukuran perusahaan terhadap tax avoidance. koneksi politik mampu memoderasi pengaruh profitabilitas terhadap tax avoidance. perusahaan yang mempunyai koneksi politik akan memudahkan dalam melakukan tax avoidance.

\section{REFERENSI}

Asadanie, N. K., \& Venusita, L. (2020). Pengaruh Koneksi Politik Terhadap Penghindaran Pajak. INVENTORY : Jurnal Akuntasi, 4(1), 14-21.

Dewi, L. K., Widiasmara, A., \& Amah, N. (2019). Pengaruh Profitabilitas Dan Manajemen Laba Terhadap Tax Avoidance Dengan Corporate Social Responsibility Sebagai Variabel Moderating Pada Perusahaan Manufaktur Yang Terdaftar Di Bursa Efek Indonesia Tahun 2015-2017. Simba (Seminar Inovasi Manajemen, Bisnis, Dan Akuntansi I), I(0), 321-333.

Faizah, S. N., \& Adhivinna, V. V. (2017). Pengaruh Roa, Leverage, Kepemilikan Institusional Dan Ukuran Perusahaan Terhadap Tax Avoidance. Jurnal Akuntansi, 5(2), 136-145. Https://Doi.Org/10.24964/Ja.V5i2.288

Khairunisa, K., Hapsari, D. W., \& Aminah, W. (2017). Kualitas Audit, Corporate Social Responsibility, Dan Ukuran Perusahaan Terhadap Tax Avoidance. Jurnal Riset Akuntansi Kontemporer, 9(1), 39-46. Https://Doi.Org/10.23969/Jrak.V9i1.366

Kompas.com. 2020. RI Diperkirakan Rugi Rp. 687 Triliun Akibat Penghindaran Pajak, (online), (https://money.kompas.com/read/2020/11/23/183000126/ri-diperkirakan-rugi-rp-68-7triliun-akibat-penghindaran-pajak, Diakses pada 30 Oktober 2021).

Krisdiantoro, I., Widiasmara, A., \& Amah, N. (2019). Pengaruh Profitabilitas, Leverage, Dan Corporate Governance Terhadap Tax Avoidance. SIMBA : Seminar Inovasi Manajemen, Bisnis, Dan Akuntansi, I(0), 292-303.

Mardianti, I. V., \& Ardini, L. (2020). Pengaruh Tanggung Jawab Sosial Perusahaan, Profitabilitas, Kepemilikan Asing, Dan Intensitas Modal Terhadap Penghindaran Pajak. Jurnal Ilmu Dan Riset Akuntansi, 9(4), 1-24.

Munawaro, M. A., \& Ramdany, R. (2020). Peran Csr, Ukuran Perusahaan, Karakter Eksekutif Dan Koneksi Politik Terhadap Potensi Tax Avoidance. Jurnal Akuntansi, 8(2), 109-121. Https://Doi.Org/10.37932/Ja.V8i2.70

Okrayanti, T. Y., Utomo, S. W., \& Nuraina, E. (2017). Pengaruh Karakteristik Perusahaan Dan Corporate Governance Terhadap Tax Avoidance (Studi Pada Perusahaan Manufaktur Di BEI). Forum Ilmiah Pendidikan Akuntansi, 5(1), 804-817.

Pajak.go.id. 2020. Praktik Penghindaran Pajak di Indonesia, (online), (https://www.pajak.go.id/id/artikel/praktik-penghindaran-pajak-di-indonesia, Diakses pada 30 Oktober 2021).

Siregar, R., \& Widyawati, D. (2016). Pengaruh Karakteristik Perusahaan Terhadap Penghindaran Pajak Pada Perusahaan Manufaktur Di Bei. Jurnal Ilmu \& Riset Akuntansi, 5(2).

Subagiastra, K., Arizona, I. P. E., \& Mahaputra, I. N. K. A. (2016). PENGARUH PROFITABILITAS, KEPEMILIKAN KELUARGA, DAN GOOD CORPORATE GOVERNANCE TERHADAP PENGHINDARAN PAJAK (Studi Pada Perusahaan 
Owner: Riset \& Jurnal Akuntansi

e-ISSN : 2548-9224 |p-ISSN : 2548-7507

Volume 6 Nomor 1, Januari 2022

Manufaktur Di Bursa Efek Indonesia). Jurnal Ilmiah Akuntansi, 1(2), 167-193. Https://Doi.Org/10.23887/Jia.V1i2.9994.

Suripto. (2021). Pengaruh Corporate Social Responsibility, Kualitas Audit dan Manajemen Laba Terhadap Tax Avoidance pada Perusahaan Pertambangan yang Terdaftar di Bursa Efek Indonesia. Jurnal Ilmiah MEA. Tangerang Selatan : Universitas Pamulang.

Suryani, S. (2020). Pengaruh Ukuran Perusahaan, Return On Asset, Debt To Asset Ratio Dan Komite Audit Terhadap Penghindaran Pajak. Jurnal Online Insan Akuntan, 5(1), 83. Https://Doi.Org/10.51211/Joia.V5i1.1322

Ulfa, M., Wijaya, A. L., \& Ubaidillah, M. (2020). Pengaruh Profitabilitas, Likuiditas, Kebijakan Hutan, Free Cash Flow Terhadap Kebijakan Dividen dengan Ukuran Perusahaan sebagai Moderasi (Studi Kasus pada Sektor Perusahaan Industri Barang Konsumsi yang Terdaftar di BEI 2015-2018. SIMBA II (Seminar Inovasi Manaejemn Bisnis dan Akuntansi II). Madiun : Universitas PGRI Madiun. 